\title{
A minus carbon eco-cycle earthen refugee shelter: a feasibility
} study

\author{
M. Dabaieh \\ Department of Urban Studies, Malmö University, Malmö, Sweden
}

\begin{abstract}
Forced migration due to wars and political conflicts create an urgent need for temporary shelters in hosting countries. Constructing new housing projects is not only economically burdensome but also requires a great deal of time and, most important, represents an environmental burden when the shelter reaches its end of life. This study discusses a design proposal for a $37 \mathrm{~m}^{2}$ eco-cycle earthen refugee shelter that could be built with the help of seven people in 11 working days. The study has adopted an experimental, participatory and living lab methodology for a physical prototype as a proof of concept. The key idea of this eco-cycle shelter is to reach net minus carbon emissions during material extraction, building construction, operation and after end of life. As this project is still ongoing, this paper will confine itself to discussing the project's main idea for reducing carbon emission and will focus on the feasibility of an earthen wall structure skeleton as a minus carbon agent. The prototype is designed for the cold climate of Sweden but the methodology can be applied in different climates. Beneficiaries of this project need not be confined to refugees. It can be extended to house the majority of the world's urban poor.
\end{abstract}

\section{INTRODUCTION}

Conflict and war have become some of the leading reasons why people are forced to leave their homes nowadays, alongside natural disasters (Aquilino, 2011). The public and private sectors in hosting countries are struggling to offer humanitarian emergency relief shelter and services (Ros-García, 2013). Emergency tents are the most common form of temporary shelter, yet these are generally expensive to make, do not offer adequate indoor thermal comfort and deteriorate quickly (Dabaieh and Borham, 2015). Their inefficiency is compounded by the additional environmental burdens that come from demolishing such temporary shelters as the majority of the common materials used are not recyclable (Obyn et al., 2015). Sweden experienced such a rapid influx of refugees during the years 2015 and 2016 that it became difficult to offer them immediate accommodation. It is apparent that innovative, cost efficient and time efficient solutions are needed to accommodate asylum seekers in temporary housing, and that this should have minimal impact on the environment after the temporary situation is over.

Reducing carbon emission from buildings during a complete life cycle from cradle to cradle is always a big challenge. It has been found that approximate $25 \%$ of global raw material extractions go into buildings (Unep, 2009). The residential building sector in Sweden accounts for $40 \%$ of the country's total energy use (Swedish Energy Agency, 2016). Earlier, drawing their findings from working on single-unit dwellings case studies in Sweden, Adalberth (1997, n.d.) have shown that $85 \%$ of the total $\mathrm{CO}_{2}$ emissions occurred during the operational building phase, while the energy used in manufacturing the construction building materials, then in the building construction and demolition phases accounted for the rest of the $15 \%$. That is confirmed by a more recent study by Peng (2016) that showed that a building's construction stages accounted for $12.6 \%$ of the total carbon emission and approximately $2 \%$ during the demolition stage, while the rest of the $85.4 \%$ was produced during operation time. A study on low energy buildings by Blengini and Di Carlo (2010) showed that the major impacts and $\mathrm{CO}_{2}$ emissions come during the building main structure manufacturing and during the maintenance phases. Equipment, construction and transportation had only a minor impact. In the same study, the authors highlighted the important role of the building material being recyclable (Blengini and Di Carlo, 2010). Even if the percentage of $\mathrm{CO}_{2}$ emis- 
sions during building construction is minimal compared to the emissions during the building operation, according to Peng (2016) this impact should not be dismissed because the average carbon emissions of non-operational stages per working area per annum are still far greater than those during the use phase. Cabeza et al. (2013) have discussed the potential to reduce carbon emissions by using building materials and building techniques with low embodied carbon during manufacturing. It has also been proved that a proper choice of materials affects the primary energy use (Gustavsson and Joelsson, 2010). As temporary shelters have a short life cycle, normally from 2 to 15 years, it definitely worthwhile reducing the embodied carbon and energy during the extraction, production, transportation and construction phases.

This study discusses an ongoing experimental living lab test to design and construct a $37 \mathrm{~m}^{2}$ minus carbon temporary earth shelter in Sweden. The mission is to build a low cost and time efficient shelter in 7 working days with the help of 11 persons, with the intention of a having minimal impact on the environment after the building's end of life. The building timescale was calculated based on the needs of three family members (two adults and one child), the workers' productivity per hour and outdoor weather limitations. Several innovative solutions were adopted for this project in order to reach a minus carbon shelter for the building's intended full life cycle. This shelter house was designed through the application of the eco-cycle home concept, and equipped with the standard necessary everyday features. The building's main skeleton is made from lightweight materials, mainly in the form of clay reinforced with the plant based fibers of straw and reeds, using lime plaster for water resistance. The natural materials are available in the local environment where the shelter will be built, which ensures minimal embodied carbon during material extraction and transportation. The design of the building is intended to eliminate the energy demands for heating and cooling to act beyond the current passive buildings standards. The house is energy self-sufficient and is equipped with renewable energy sources. It is calculated to produce more energy than it consumes and to transport the excess back to the national energy grid for later use, should there be a deficiency in energy production.

The idea behind the design of the shelter is also based on the 5 Rs concept (Refuse, Reduce, Reuse, Recycle and Rot). Mainly the idea is to Refuse to use any toxic industrial material for building construction; to Reduce the use of all energy and carbon intensive materials or construction techniques; to Reuse all waste outcomes from the shelter during its time of operation and equally to Reuse the construction waste after the shelter's end of life so as to close the loop and achieve a full eco-cycle shelter over its lifetime; to Recycle the waste products that cannot be reused; and finally, at the end of the building's life cycle, it should decompose back to nature as Rot, with minimal if not zero impact on the environment, apart from what can be reused as building material.

The different low tech wall compositions have been selected to achieve minimal carbon emission during extraction, manufacturing and construction while still taking into account the availability of the material, its feasibility for construction and its cost efficiency. The thermal performance of the proposed walls is also being taken into account as that affects the building's total energy consumption for heating and cooling loads during the building's operation. The main materials proposed for the building's skeleton, which are all capable of contributing to the minus carbon effect after the building's end of life are clay, lime and three plant based materials: straw, reeds and wood. The project idea also tried to work on previous problems in exiting shelters specially when it comes to maintenance or the need for replacements and repairs. In addition, it integrated lessons from vernacular and local architecture building methods in Scania region in Sweden. As this project still ongoing, this paper will be just focusing on the design stage of the building's main skeleton wall structure and the calculations to reach a minus carbon outcome.

\section{METHODOLOGY}

\subsection{Investigative survey analysis}

The process started in this study by investigative analysis for possible building materials and techniques for the shelter prototype building skeleton. First the investigative study was made in the Scania region in Sweden to search for traditional vernacular building techniques and natural building materials available for possible current use. This phase incorporated both literature search and site visits for museums and existing vernacular sites. The main aim was to assess what features could be learned from vernacular techniques while trying to improve such techniques for more resilient and climatic adaptable solutions for a temporary refugee shelter.

\subsection{Wall cross section design alternatives}

Based on the investigative study, several wall composition alternatives were designed applying the eco-effectiveness concept discussed by Braungart et al., (2007). That would be achieved by designing a shelter skeleton with less waste and toxicity with possible recyclability or reuse and at the same time suiting social and economic constraints. Straw bale with reeds and a coating layer from clay plastering and lime render 
were the main elements in the wall skeleton design. The layers were alternated in different orders and with different thickness to reach the optimal thermal performance, $U$ value and the least probabilities for moisture content and summer heat protection. Passive house premium standard was the target to reach. Five different solutions were designed using the U-Wert web tool. Calculations were made for U-values for the wall structure proposals and were compared to each other to choose the best applicable and feasible ones.

\subsection{Carbon life cycle calculation during}

\section{construction}

The total amount of $\mathrm{CO}_{2}$ emissions during the building stage of the refugee shelter, including the emissions from the material production, transportation and construction, were calculated following the same method of calculation as Peng (2016). However, the equation he used in his study was developed to suit this project case for calculating the total carbon emissions.

$C_{\text {total }}=C_{e}+C_{p}+C_{t}+C_{c}-C_{s}$

where $C_{\text {total }}$ is the total $\mathrm{CO}_{2}$ emissions generated during building process, $C_{e}$ is the total $\mathrm{CO}_{2}$ emissions from building material extraction, $C_{p}$ from material production, $C_{t}$ from material transportation, and $C_{c}$ from construction; $C_{s}$ is the total carbon sequestration by the plant based material during growing process. All the units are in $\mathrm{kg}$ and the amount of material used is calculated for the whole building. All figures are obtained from field investigations for this specific case. This phase will be followed by calculations for the financial and energy payback period for the chosen alternative. Then a proof of concept test cell for a wall sample will be constructed in an urban living lab. Material lab tests for compression, tension strength and water resistivity will be performed. This part will not be discussed in this paper.

\section{RESULTS}

\subsection{Literature study and site survey outcome}

The investigative study revealed that several vernacular construction techniques were applied in the past in Scania using natural local materials such as mud bricks, straw, reeds, stone and wood. Earth techniques such as adobe, pisé and cast lime mortar were the main methods in use between the 1750s and the 1950s in Sweden (Palmgren, 2003). Several lessons were derived from the traditional vernacular systems that exist in Scania region and were confirmed by looking at the availability of local natural resources (clay, lime, reeds and straw). Different types of clay are abundant and of very good quality suitable for use as abode, rammed earth and cast earth. The same for reeds and straw, which can be used for both roof and wall construction. Reed is an available material in the southern part of Sweden, growing around the region's lakes and rivers however, it is seldom used. On the other hand, straw is more often used in straw bale structures though on a limited scale. Lime is mainly used in final render; mixed with plaster as a binding material, in construction techniques such as cast limemortar buildings, or it is capable of being moulded into slag lime buildings. Lime is still used in Scania in conservation and restoration processes for both old buildings and on a limited scale as a plaster in contemporary ones. One factory was found in Scania that still produces good quality of lime in the traditional way.

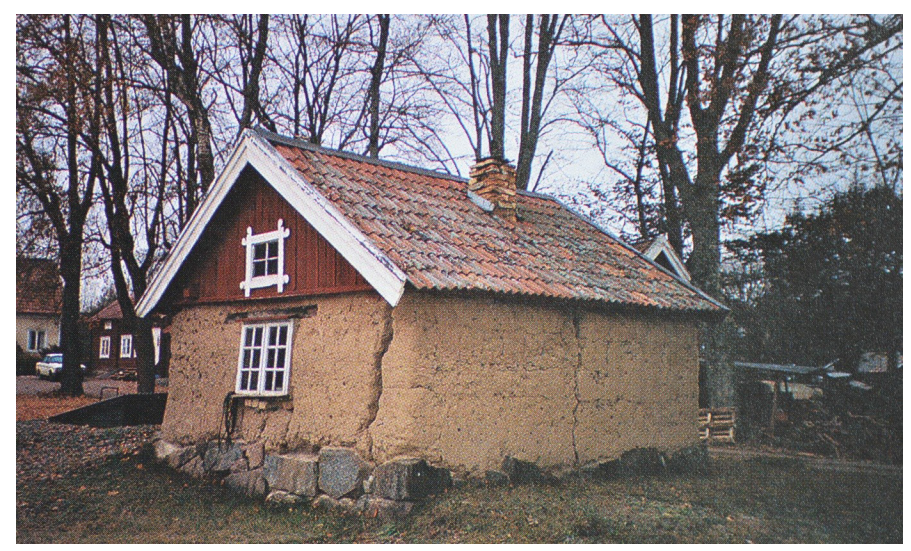

Figure 1. Example of an earth building from the early 18th century in Sweden. Photo credit: Karin Blent. Courtesy Upplands Museum.

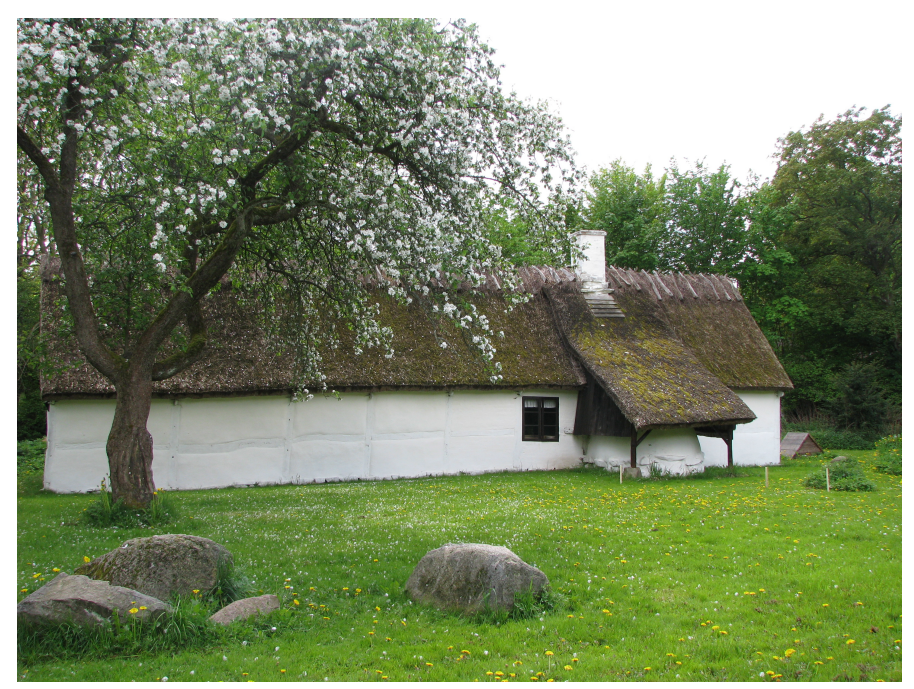

Figure 2. Vernacular buildings constructed from Adobe and plastered with lime in Scania, Sweden. 


\subsection{Design alternatives and best design outcome}

For the parametric alternatives for the wall composition, the five different alternatives are shown in Table (1). Different thicknesses for the straw, reeds, clay and lime plastering layers were tested. The worst alternative with highest $U$ value of $0.200 \mathrm{~W} / \mathrm{m}^{2} \mathrm{~K}$ and the highest moisture content were the ones when the straw layer had a minimum thickness of $220 \mathrm{~mm}$. After increasing the straw bale thickness to $300 \mathrm{~mm}$ and reducing the lime render from $10 \mathrm{~mm}$ to $2 \mathrm{~mm}$ the $\mathrm{U}$ value was improved to $0.153 \mathrm{~W} / \mathrm{m}^{2} \mathrm{~K}$. When the reed layer was increased to a thickness of $70 \mathrm{~mm}$, instead of $10 \mathrm{~mm}$ in the alternatives one and two, while the straw bale was again reduced to $220 \mathrm{~mm}$, the U value was cut to $0.123 \mathrm{~W} / \mathrm{m}^{2} \mathrm{~K}$. Adding another internal clay plastering layer of $3 \mathrm{~mm}$ and reducing the reed thickness to $50 \mathrm{~mm}$ improved the $\mathrm{U}$ value to 0.112 $\mathrm{W} / \mathrm{m}^{2} \mathrm{~K}$. The best $\mathrm{U}$ value obtained was 0.099 $\mathrm{W} / \mathrm{m}^{2} \mathrm{~K}$, when the reed layer was $70 \mathrm{~mm}$.

The first alternative was the only alternative that showed a problem with moisture content as it produced condensation of $1,14 \mathrm{~kg} / \mathrm{m}^{2}$, but the other four alternatives showed no possibility for condensation occurring if the indoor temperature was a minimum $19.5^{\circ} \mathrm{C}$ and the outdoor a minimum $5{ }^{\circ} \mathrm{C}$, leading to a relative humidity of $52 \%$ to $51 \%$. The time lag ranged from 12 hours in the first alternative to 20 hours in alternative five.

Table (1) The five-proposed wall cross sections using the UWert web tool showing the layers, wall thickness and total $U$ value of each.
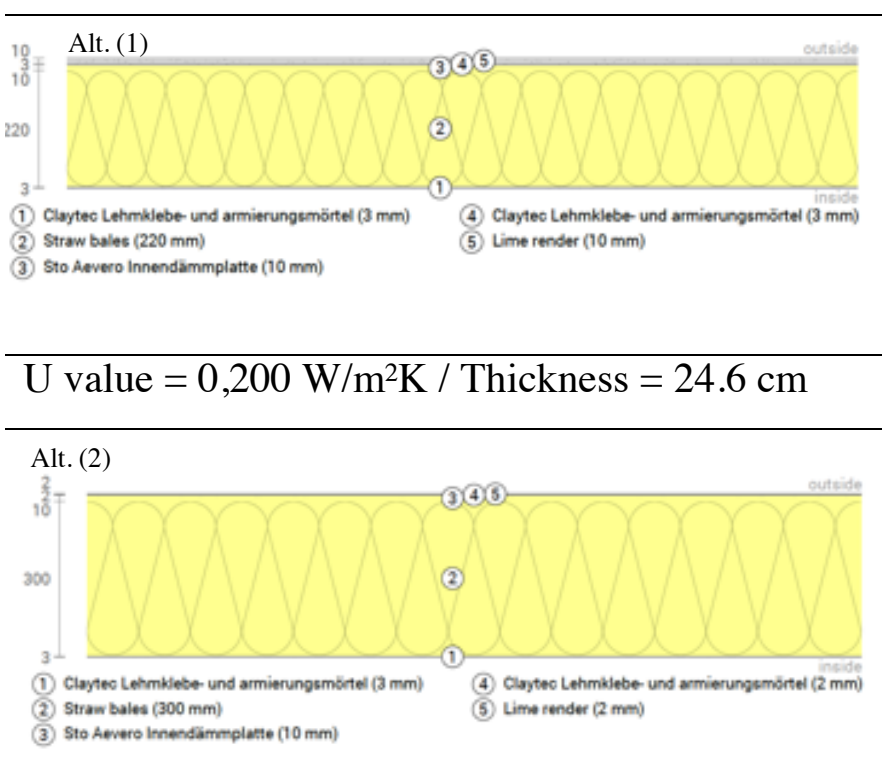

$\mathrm{U}$ value $=00,153 \mathrm{~W} / \mathrm{m}^{2} \mathrm{~K} /$ Thickness $=31.7 \mathrm{~cm}$

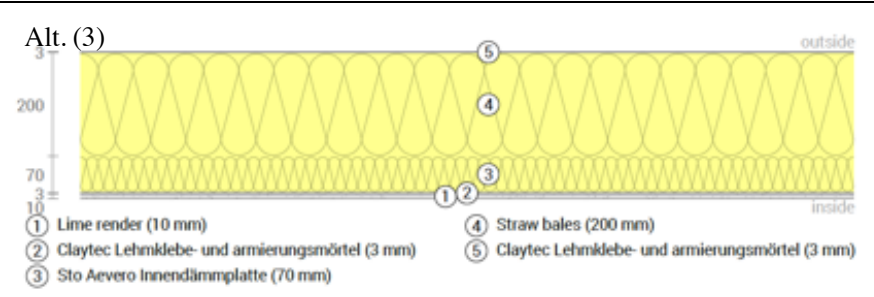

$\mathrm{U}$ value $=0,123 \mathrm{~W} / \mathrm{m}^{2} \mathrm{~K} /$ Thickness $=28.6 \mathrm{~cm}$

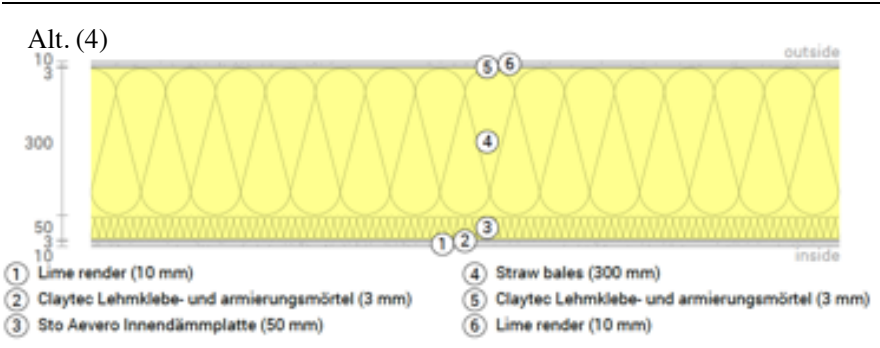

$\mathrm{U}$ value $=0,112 \mathrm{~W} / \mathrm{m}^{2} \mathrm{~K} /$ Thickness $=37.6 \mathrm{~cm}$

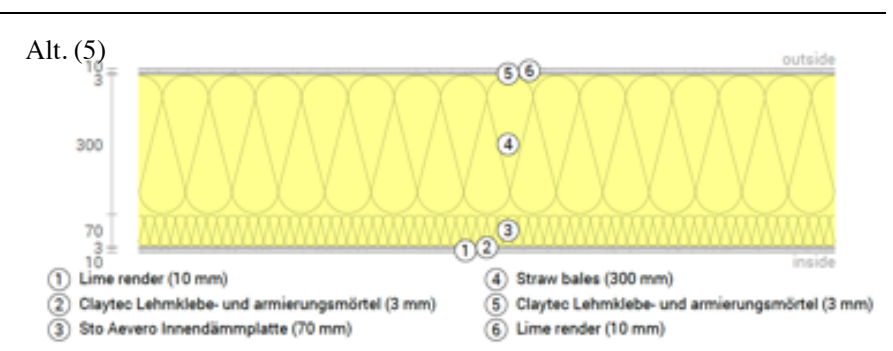

$\mathrm{U}$ value $=0,099 \mathrm{~W} / \mathrm{m}^{2} \mathrm{~K} /$ Thickness $=39.6 \mathrm{~cm}$

\subsection{Life cycle carbon emission calculation and minus carbon potential}

The total carbon emission of the wall structure calculated for the different building materials during extraction, production, transportation and manufacturing then subtracted from carbon sequestration using eq1 (1). The total emissions calculated for transportation of the clay, straw and reeds are based on calculating the actual emission using vehicles from the neighbouring farms to the proposed site for this project within a $2-\mathrm{km}$ proximity. As for lime the figures calculated for extraction, manufacturing and production were obtained from the lime factory and the $\mathrm{CO}_{2}$ emissions are calculated for the transportation from the factory to the site over a distance of $49 \mathrm{~km}$. The $\mathrm{CO}_{2}$ emissions of the plant based material were calculated during their growth as well for their carbon reduction potential. The calculations for production were made for the cutting and piling of reeds and straw. The total results of carbon emissions is minus $82.5 \mathrm{~kg} \mathrm{CO} / \mathrm{m}^{2}$ of the shelter prototype. 


\section{DISCUSSION}

This study has targeted carbon emission reduction possibilities during the construction of refugee shelters. This was achieved by using natural material with low embodied energy and carbon throughout the whole building process with a minus carbon potential as a net outcome. Normally temporary crisis shelters are constructed to last for short periods; the time varies from 2 to 15 years, after which they are demolished, leaving environmental burdens from construction wastes. These features occur in addition to the relatively poor thermal performance and quality of construction. To contrast with this approach, in this project local indigenous natural materials were favoured to create the pilot building for the same end use as this offers low impact environmental qualities and will reduce the construction waste at the building's end of life. Additional advantages are that the indoor air quality is good because the walls are from a natural non-hazardous material; similarly with thermal properties that made the house more energy efficient in terms of heating and cooling demands. One of the benefits is that the techniques are easy to learn, which opens the possibility of involving the refugees in the construction process, a development which would potentially reduce labour costs and energy for labour transportation.

The proposed main wall skeleton in this shelter consists of mixed composite layers of straw, reeds, clay and lime, a combination which has shown a good performance reaching a $U$ value of $0.99 \mathrm{~W} / \mathrm{m}^{2} \mathrm{~K}$, which complies with passive house standards. Both straw and reeds also serve as thermal and sound insulation materials in addition to acting as a main structure element. Reeds are an especially useful material as they allow air flow, which reduces moisture content (Dabaieh and Sakr, 2015). Both are breathable materials so they enhance indoor air quality and reduce the possibility for moisture or moulds to occur. Reeds when bundled with steel mesh wires enhance the stability of the walls and act as structural support, shown in figure (3). When it comes to carbon reduction, straw and reeds, being plant based materials, absorb $\mathrm{CO}_{2}$ during their growth, a process that continues when they are mixed with wet clay as the resultant material decomposes partially into cellulose which, in turn, acts as a binding agent.

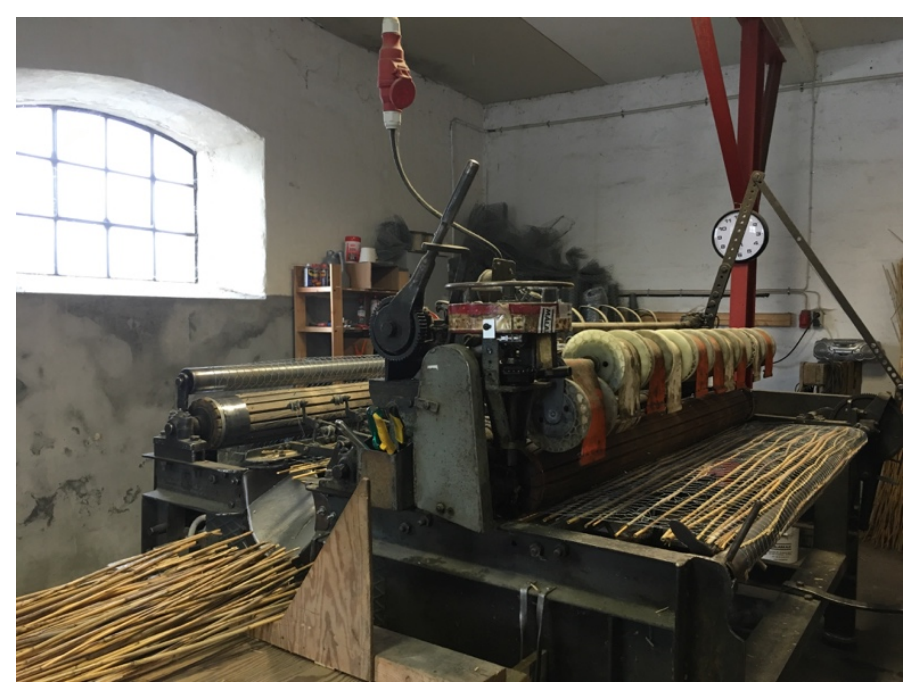

Figure 3. A traditional machine for making reed mats with steel wire mesh in Scania, Sweden.

Lime takes in $\mathrm{CO}_{2}$ throughout the construction process and building operation where there in an increase in indoor air humidity. It will even increase the carbon sequestration potential if calculated over the operation time along the lifetime of the temporary shelter. As a traditional material, lime has proved to be soft and succulent to apply. It is even more durable when mixed with sand. As for maintenance, a limeplastered wall will need to be maintained twice over a life span of 15 years, which is done by plastering the external walls with lime wash to increase its resistance to rain and snow.

This study has contributed in showing how choosing the proper material can reduce the embodied carbon during building construction and can reach a minus carbon outcome. There is a potential in using the suggested wall constructed from natural materials as that will reduce the energy and carbon emissions when dealing with construction waste after the shelter's end of life. Early studies have shown that reducing an operation's energy increases the energy for material production (Keoleian et al., 2001; Thormark, 2002); however, the argument in this study is that reducing the material energy production with enhanced thermal properties will consequently reduce the operating energy. However according to Peng (2016) approximately $85.4 \%$ of total carbon emissions are generated during a building's operation. Thus, this study is intended to be followed by another intensive study in carbon reduction strategies during building operation. As the preliminary results of this study have shown, there is a potential for energy consumption reduction especially for heating and cooling (which is the most energy consuming element during a building's operation) because of the $U$ value of the proposed wall. A further potential yet exists for reduction of the total carbon emissions during the operating phase of this shelter prototype. Moreover, using resource efficient 
materials and low tech solutions offers adequate adaptation to the local conditions and when acute situations arise to offer low cost and quick shelters with the addition of dignified habitability. The results of this study provide an insight into the effect of using renewable materials like straw and reeds together with clay and lime on the total $\mathrm{CO}_{2}$ emissions and the relevance of carbon storage potential to reach a minus carbon outcome. One of the indirect benefits of this project is also to revitalize some of the traditional building technologies in Scania, that are on the verge of disappearing as many other places in the world.

\section{CONCLUSION}

Building wall design can affect the environmental impacts of the various life stages of building. The proposed wall construction solutions in this study are a first step for the project shelter design. They have shown how vernacular material and traditional techniques when developed have the potential for a betterquality emergency shelter. The choice of renewable energy-based raw materials and reduction of fossil fuel use in material production and construction can contribute significantly in reducing primary energy and $\mathrm{CO}_{2}$ emissions through a building's life cycle. The project has also a high potential for reversibility, reuse and/or recycling with minimal impact on the environment. There is a great deal more to be done for the complete design of the project to be followed in the coming research steps.

\section{ACKNOWLEDGEMENT}

The author would like to acknowledge Crafoord and ÅForsk foundations, the main sponsors for this project.

\section{REFERENCES}

Adalberth, K., 1997. Energy use during the life cycle of buildings: a method. Build. Environ. 32, 317-320. doi:http://dx.doi.org/10.1016/S0360-1323(96)00068-6

Adalberth, K., n.d. Energy use during the life cycle of singleunit dwellings: Examples. Build. Environ.

Aquilino, M.J. (Ed.), 2011. Beyond shelter : architecture for crisis. Thames \& Hudson, London.

Blengini, G.A., Di Carlo, T., 2010. Energy-saving policies and low-energy residential buildings: an LCA case study to support decision makers in Piedmont (Italy). Int. J. Life Cycle Assess. 15, 652-665. doi:10.1007/s11367-010-0190-5

Braungart, M., McDonough, W., Bollinger, A., 2007. Cradle-tocradle design: creating healthy emissions - a strategy for eco-effective product and system design. J. Clean. Prod. 15, 1337-1348. doi:http://dx.doi.org/10.1016/j.jclepro.2006.08.003

Cabeza, L.F., Barreneche, C., Miró, L., Morera, J.M., Bartolí, E., Inés Fernández, A., 2013. Low carbon and low embodied energy materials in buildings: A review. Renew. Sustain. Energy Rev. 23, 536-542. doi:http://dx.doi.org/10.1016/j.rser.2013.03.017

Dabaieh, M., Borham, A., 2015. Acclimatization Measures for Temporary Refugee Shelters in Hot Arid Climates; LowTech Mobile Solutions Using Bedouin Tents, in: Cucinella, M., Floriani, G., Fagnani, A., D’Ambrosio, L. (Eds.), Architecture in $(\mathrm{R})$ Evolution. 31st International PLEA Conference. Ass.Building Greeen Futuers, Bologna.

Dabaieh, M., Sakr, M., 2015. Building with Reeds: Revitalizing a Building Tradition for Low Carbon Building Practice, in: Khanjanusthiti, P., Poshyanandana, S.P., Hwungklibsukon, P. (Eds.), International Conference CIAV+ICTC 2015“ Timber Heritage and Cultural Tourism:Values, Innovation and Visitor Management." Amarin Printing and Publishing Public Company Limited, Bangkok, pp. 72-88.

Gustavsson, L., Joelsson, A., 2010. Life cycle primary energy analysis of residential buildings. Energy Build. 42, 210-220. doi:10.1016/j.enbuild.2009.08.017

Keoleian, G. a, Blanchard, S., Reppe, P., 2001. Life-Cycle Energy, Costs, and Strategies for Improving a Single-Family House. J. Ind. Ecol. 4, 135-156. doi:10.1162/108819800569726

Obyn, S., van Moeseke, G., Virgo, V., 2015. Thermal performance of shelter modelling: Improvement of temporary structures. Energy Build. 89, 170-182. doi:10.1016/j.enbuild.2014.12.035

Palmgren, L.A., 2003. Svenska jordhus med lera eller kalk 17501950 : om olika svenska jordhusmetoder - när, varför och hur de uppfördes, Trita-ARK. Forskningspublikation, 14027453 ; 2003:5. Kungliga tekniska högskolan, Arkitekturskolan, Stockholm.

Peng, C., 2016. Calculation of a building's life cycle carbon emissions based on Ecotect and building information modeling. J. Clean. Prod. 112, Part, 453-465. doi:http://dx.doi.org/10.1016/j.jclepro.2015.08.078

Ros-García, J.M., 2013. Humanizing Architecture in Emergencies: Towards an Improved Model of Basic Settlement without Negative Impact. Int. J. Constr. Environ. 4, 25-39.

Swedish Energy Agency, 2016. Energy Indicators in figures 2016 - Follow-up of Sweden's energy policy goals [WWW Document]. Energy Indic. Fig. 2016 - Follow. Sweden's energy policy goals. URL http://www.energimyndigheten.se/en/news/2016/energy-indicators-in-figures2016---follow-up-of-swedens-energy-policy-goals/ (accessed 6.20.06).

Thormark, C., 2002. A low energy building in a life cycle-its embodied energy, energy need for operation and recycling potential. Build. Environ. 37, 429-435. doi:10.1016/S03601323(01)00033-6

Unep, 2009. Buildings and climate change: a summary for decision-makers. United Nations Environ. Program. Sustain. Build. Clim. Initiat. 1-62. doi:ISBN: 987-92-807-3064-7 DTI/1240/PA 